\title{
B-1 Cell Lymphoma in Mice Lacking the Steroid and Xenobiotic Receptor, SXR
}

\author{
Stephanie C. Casey, Edward L. Nelson, Gina M. Turco, Matthew R. Janes, \\ David A. Fruman, and Bruce Blumberg \\ Departments of Developmental and Cell Biology (S.C.C., G.M.T., B.B.), Molecular Biology and \\ Biochemistry (E.L.N., M.R.J., D.A.F.), and Pharmaceutical Sciences (B.B.) and Department of Medicine, \\ Hematology/Oncology Division (E.L.N.), University of California, Irvine, California 92697
}

\begin{abstract}
The steroid and xenobiotic receptor (SXR) is a broad-specificity nuclear hormone receptor that is highly expressed in the liver and intestine, where its primary function is to regulate drug and xenobiotic metabolism. SXR is expressed at lower levels in other tissues, where little is known about its physiological functions. We previously linked SXR with immunity and inflammation by showing that SXR antagonizes the activity of nuclear factor (NF)- $\kappa \mathrm{B}$ in vitro and in vivo. SXR ${ }^{-1-}$ mice demonstrate aberrantly high NF- $\kappa$ B activity and overexpression of NF- $\kappa$ B target genes. Here we show that $S X R^{-1-}$ mice develop B cell lymphoma in an age-dependent manner. $S X R^{-1-}$ mice develop multiple hyperplastic lymphoid foci composed of B-1a cells in the intestine, spleen, lymph nodes, peritoneal cavity, and blood. In all circumstances, these lymphocytes possess cell surface and molecular characteristics of either chronic lymphocytic leukemia or non-Hodgkin's lymphoma originating from B-1 lymphocytes. These results demonstrate a novel and unsuspected role for SXR signaling in the B-1 cell compartment, establish SXR as a tumor suppressor in B-1 cells, and may provide a link between metabolism of xenobiotic compounds and lymphomagenesis. (Molecular Endocrinology 25: 933-943, 2011)
\end{abstract}

$\mathbf{T}$ he steroid and xenobiotic receptor (SXR) (also known as PXR, PAR, and NR1I2) is a broad-specificity, low-affinity nuclear hormone receptor that is activated by numerous drugs, xenobiotic chemicals, and dietary compounds. Strong SXR activators include rifampicin, taxol, mifepristone, clotrimazole, phenytoin, and hyperforin (reviewed in Ref. 1). The primary function of SXR is thought to be the transcriptional regulation of xenobiotic metabolism enzymes such as cytochrome P450 (CYP) genes, conjugating enzymes, and $\mathrm{ABC}$ family transporters.

We and others previously showed that SXR and the nuclear factor (NF)- $\kappa$ B signaling pathways are mutually inhibitory in vitro and in vivo $(2,3)$. NF- $\kappa \mathrm{B}$ is widely expressed and functions as a key regulator of the immune response and inflammation. $S X R^{-1-}$ mice express high

ISSN Print 0888-8809 ISSN Online 1944-9917

Printed in U.S.A.

Copyright (C) 2011 by The Endocrine Society

doi: 10.1210/me.2010-0486 Received November 22, 2010. Accepted March 1, 2011

First Published Online March 24, 2011 levels of NF- $\kappa \mathrm{B}$ target genes in tissues with robust SXR expression, such as the liver and intestine, and chronic inflammation was found in knockout (KO) animals. SXR activators inhibit the expression of NF- $\kappa \mathrm{B}$ target genes in vitro and in vivo in an SXR-dependent fashion (2). Inhibiting NF- $\kappa \mathrm{B}$ activity augmented SXR induction of its target genes, whereas NF- $\kappa \mathrm{B}$ activation blunted SXR signaling and decreased expression of genes encoding drug-metabolizing enzymes such as CYP4A4 $(2,3)$.

Considering that NF- $\kappa \mathrm{B}$ is intimately involved in immune function and that disruption of NF- $\kappa \mathrm{B}$ has been previously implicated in a wide range of biological disorders (4), we inferred that disruption of SXR and consequent chronic activation of NF- $\kappa \mathrm{B}$ would lead to significant in vivo consequences. Among its many known functions, NF- $\kappa$ B regulates both the proliferation of lym-

Abbreviations: APC, Allophycocyanin; CAPE, caffeic acid phenethyl ester; CLL, chronic lymphocytic leukemia; FITC, fluorescein isothiocyanate; KO, knockout; NF, nuclear factor; NOD/SCID, non-obese diabetic/severe combined immunodeficiency mice; PCB, polychlorinated biphenyl; PCN, pregnenolone-16-carbonitrile; PE, phycoerythrin; PTPN6 protein tyrosine phosphatase, non-receptor type 6; qRT-PCR, quantitative real-time PCR; SLL, small lymphocytic lymphoma; SXR, steroid and xenobiotic receptor; WT, wild type; Zap70, Zeta-chain-associated-protein kinase 70. 
TABLE 1. SXR down-regulation in lymphatic tumors (Oncomine)

\begin{tabular}{|c|c|c|c|c|c|c|c|}
\hline Zhan myeloma 3 & $\begin{array}{l}\text { Monoclonal Gam. of } \\
\text { Und. Sig. }\end{array}$ & 44 & Bone marrow & -0.072 & 22 & -0.353 & $4.76 \times 10^{-5}$ \\
\hline Andersson leukemia & $\begin{array}{l}\text { B cell acute lymphoblastic } \\
\text { leukemia }\end{array}$ & 87 & Bone marrow & 0.341 & 6 & -1.106 & $2.34 \times 10^{-4}$ \\
\hline Basso lymphoma & Burkitt's lymphoma & 17 & B lymphocytes & 0.11 & 5 & -0.204 & 0.02 \\
\hline Basso lymphoma & Hairy cell leukemia & 16 & B lymphocytes & 0.11 & 5 & -0.207 & 0.043 \\
\hline Andersson leukemia & $\begin{array}{l}\text { T cell acute lymphoblastic } \\
\text { leukemia }\end{array}$ & 11 & Bone marrow & 0.341 & 6 & -0.412 & 0.065 \\
\hline Zhan myeloma 3 & Smoldering lymphoma & 12 & Bone marrow & -0.072 & 12 & -0.431 & 0.091 \\
\hline Basso lymphoma & $\begin{array}{l}\text { Diffuse large B cell } \\
\text { lymphoma }\end{array}$ & 32 & B lymphocytes & 0.11 & 5 & -0.169 & 0.101 \\
\hline
\end{tabular}

SXR expression data from selected microarray studies deposited in Oncomine.

phocytes and lymphocyte apoptosis (3). Sustained NF- $\kappa$ B up-regulation has been previously shown to drive transformation of lymphocytes to lymphatic tumors during chronic infection; notably, gastric mucosa-associated lymphoid tissue lymphoma has been linked to persistent Helicobacter pylori infection (5). Furthermore, chronic inflammation raises the risk of other types of cancer; for example, inflammatory bowel disease is associated with the development of colon cancer, and prostatitis is linked to the development of prostate cancer (6). Additional data support a causal association between NF- $\kappa \mathrm{B}$ and oncogenesis (reviewed in Refs. 6 and 7). There is clear evidence that NF- $\kappa \mathrm{B}$ is involved in tumor initiation and development in tissues in which cancer-associated inflammation is often seen, such as the liver and intestine $(8,9)$.

Our analysis of $S X R^{-/-}$animals of increasingly advanced age revealed that, in addition to the intestinal inflammation found in young animals (2), older animals developed an influx of B-1 cells. Beginning at 6 months of age, we observed multifocal lymphomas in the intestine, spleen, and lymph nodes comprised of B-1 cells. This phenotype was observed in both sexes, although a higher penetrance was observed in females, a phenomenon consistent with other studies of sexually dimorphic immune function (10-12). B-1 cells isolated from the spleen could be passaged ex vivo without mitogenic stimulation and could be serially transplanted in nonobese diabetic/severe combined immunodeficiency (NOD/SCID) mouse hosts. This study suggests that SXR plays a crucial role in the creation and expansion of B-1 cells and that $S X R$ acts as a tumor suppressor gene in B-1 cells. Moreover, $S X R^{-1-}$ mice may serve as a tool to study chronic lymphocytic leukemia (CLL)/small lymphocytic lymphoma (SLL) and other lymphatic malignancies such as mantle cell lymphoma.

\section{Results}

\section{$S X R^{-/-}$mice develop a lymphoproliferative syndrome that progresses with age}

To investigate a potential role of SXR in NF- $\kappa \mathrm{B}$-mediated oncogenesis, we analyzed human cancer transcriptome profiles for SXR expression. Published studies summarized in the Oncomine database showed that $S X R$ may be downregulated in several premalignant states and lymphatic tumors (Table 1), including B cell malignancies such as B cell acute lymphoblastic leukemia, centroblastic lymphoma, and Burkitt's Lymphoma as well as diffuse large B cell lymphoma, mantle cell lymphoma, and CLL. To determine whether loss of SXR might be a cause rather than an effect of B lymphoid transformation, we examined lymphoid tissue in $S X R^{-/-}$animals and found large lymphoid accumulations in the spleen, lymph nodes, and intestine with increasing age (Fig. 1, A and C). This progressive evolution of lymphoproliferative lesions (Fig. 1A) was found in approximately $75 \%$ of males and $85 \%$ of females. Lymphocyte proliferation was first evident in the intestine, an area of high SXR expression in wild-type (WT) mice. Enlarged Peyer's patches and intestinal inflammation were noted at 8 $\mathrm{wk}$, accompanied by a strong up-regulation of proinflammatory genes, in accord with our previous findings (2). Splenomegaly was observed beginning at $20 \mathrm{wk}$. Intestinal tumors were evident at 20-24 wk, and lymph node tumors developed in some animals. Apparent tumors were observed in other organs by $24-28 \mathrm{wk}$ of age. $S X R^{-1-}$ spleens were 
A Enlarged Peyer's Patches, Pro-Inflammatory

Genes Elevated (8 weeks)

Splenomegaly (20 weeks)

Intestinal Tumors,

Enlarged Lymph Nodes (20-24 weeks)

B

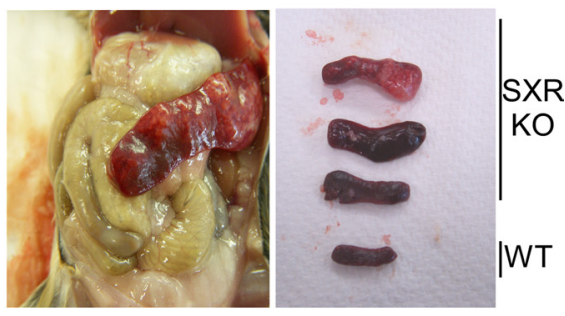

Splenic, Hepatic,

Pancreatic Tumors (24-28 weeks)

C

Intestine
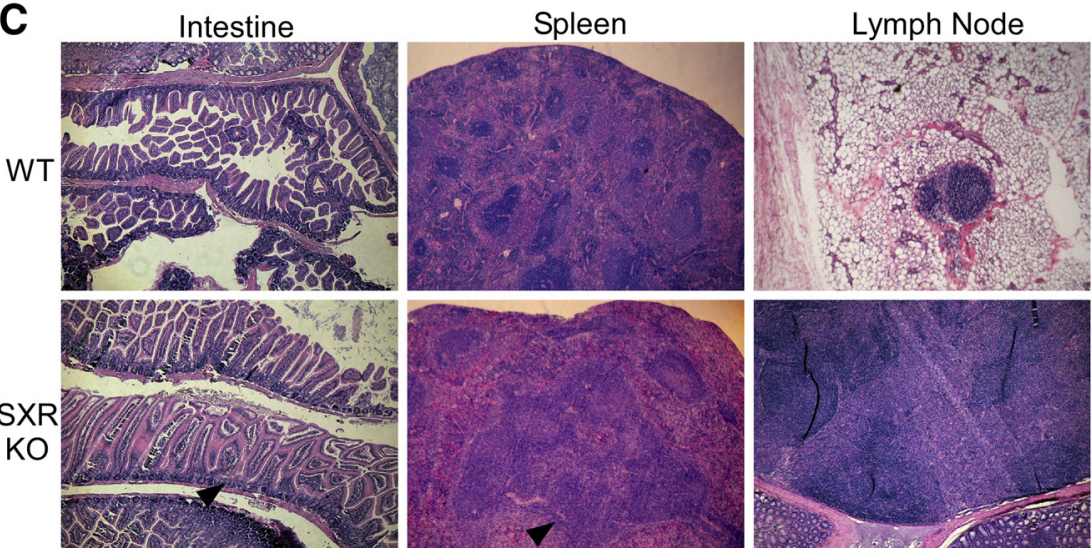

FIG. 1. $S X R^{-1-}$ mice develop a lymphoproliferative syndrome that progresses with age. $A$, $S X R^{-1-}$ animals develop severe inflammation and acute lymphoproliferations and ultimately develop lymphoma; $\mathrm{B}$, spleens of aged $S X R^{-1-}$ animals are enlarged, ranging from $0.2-1 \mathrm{~g}$ (as compared with $0.1 \mathrm{~g}$ for strain- and age-matched control animals); $\mathrm{C}$, hematoxylin- and eosinstained slides for WT and $\mathrm{KO}$ animals indicate inflammation, lymphoproliferation, and disruption of normal architecture in aged SXR KO animals. Original magnification for all panels, $\times 40$.
No changes in macrophages, dendritic cells, B- 2 cells, or $\mathrm{CD}^{+}{ }^{+} \mathrm{T}$ cells were observed. Flow cytometric analysis of $\mathrm{IgM}^{+}$cells revealed a significant expansion in the total number of $\mathrm{CD}^{+} /$ B220 intermediate $\mathrm{B}-1 \mathrm{a}$ cells in the spleen and the lymph node of aged $S X R^{-\prime-}$ animals compared with strain- and agematched control mice (Fig. 2A); B-1a cells are not normally present in large numbers in the spleens or lymph nodes (15). This $\operatorname{IgM}^{+} / \mathrm{B} 220^{\text {intermediate }}$ population frequently reached approximately $20 \%$ of total splenocytes in SXR ${ }^{-1-}$ animals vs. $0-2 \%$ in WT animals (Fig. 2A). The proportion of B-1a cells recovered from peritoneal lavage and in the peripheral blood tripled in $\mathrm{KO}$ animals (Fig. 2B), and the total cell yield from peritoneal lavage increased in $\mathrm{KO}$ animals (Supplemental Fig. 2). These B-1 cells also expressed CD21 and CD38 (Supplemental Fig. 3), markers expressed on CLL/SLL cells, a disease thought to be of B-1a cell origin (17). CD38 is used as a clinical marker for poor prognosis and the need for aggressive treatment of CLL/SLL (18).

The number of $B$ cells expressing $\kappa$ or $\lambda$ light chain normally remains conenlarged, ranging in weight from $0.2-1 \mathrm{~g} v$ s. $0.1 \mathrm{~g}$ in controls (Fig. 1B) and showed expansion of the white pulp with pronounced effacement of the germinal center regions (Fig. 1C). Inguinal, axillary, brachial, and cervical lymph nodes were enlarged 5- to 15-fold compared with WT animals (Fig. 1C).

\section{$S X R^{-/-}$mice have a lymphoproliferative disorder that involves B-1a B cells}

B-1 cells are produced in the fetal liver and then migrate to the peritoneum and to Peyer's patches in the intestine $(13,14)$, all areas of high SXR expression. B-1 cells $\left(\mathrm{CD}^{+}, \mathrm{IgM}^{\text {high }}\right.$, and $\left.\mathrm{B} 220^{\text {intermediate }}\right)$ are distinguished from conventional B- 2 cells $\left(\operatorname{IgM}^{+} / \operatorname{IgD}^{+} / \mathrm{B} 220^{+}\right)$ by unique surface markers, the capacity to self-replenish, and a restricted tissue distribution $(13,15,16)$. B-1 cells can be subdivided into B-1a cells, which express CD5, and B-1b cells, which do not (13).

We next characterized the nature of cells contributing to the splenomegaly and lymphadenopathy in aged $S X R^{-/-}$ animals. Consistent with an inflammatory environment, we found moderate increases in neutrophils and $\mathrm{CD} 8^{+} \mathrm{T}$ cells (Supplemental Fig. 1, published on The Endocrine Society's Journals Online web site at http://mend.endojournals.org). stant. In humans, the ratio varies from 50:50 to 65:35, whereas $90-95 \%$ of mouse B cells express the $\kappa$ light chain for a ratio of 20:1 $(19,20)$. $S X R^{-/-}$mice demonstrate an elevated $\kappa$ to $\lambda$ ratio (a change from 20:1 $\kappa$ to $\lambda$ to $100 \% \kappa)$, suggestive of a monoclonal expansion of a B cell subpopulation (Fig. 2C). An altered $\kappa$ to $\lambda$ ratio is also used as a diagnostic criterion for $\operatorname{CLL} / \operatorname{SLL}(21,22)$. Analysis of the $\mathrm{V}_{\mathrm{H}} \mathrm{DJ}_{\mathrm{H}}$ sequences of the $\mathrm{V}_{\mathrm{H}} \mathrm{DJ}_{\mathrm{H}}$-Cmu transcripts from $S X R^{-1-}$ splenocytes revealed that $35 \%$ of all transcripts present had identical length and alignment. DNA sequencing and bioinformatic analysis suggested that these were a clonal population (Supplemental Fig. 4). These results are consistent with the presence of B-1a B cell monoclonal lymphoproliferative disease in $S X R^{-/-}$ animals.

Decreased body weight and splenomegaly are associated with lymphoproliferative syndrome and lymphoma, resulting in an increase in the spleen to body weight ratio $(23,24)$. Aged female $S X R^{-1-}$ mice weigh less than $21 \mathrm{~g}$ compared with $24 \mathrm{~g}$ for WT animals and have a concomitant increase in the spleen to body weight ratio (Fig. 2D). 

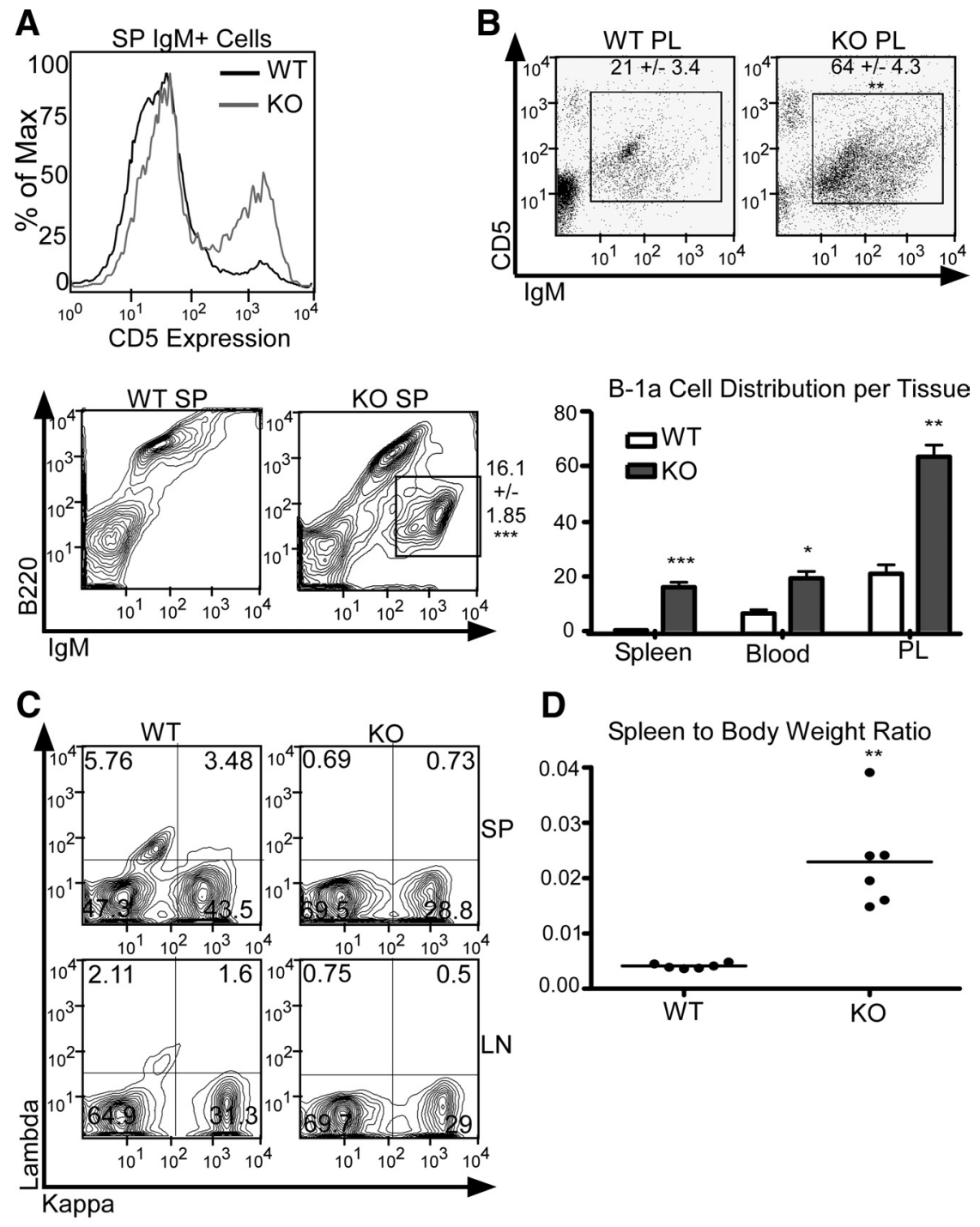

D

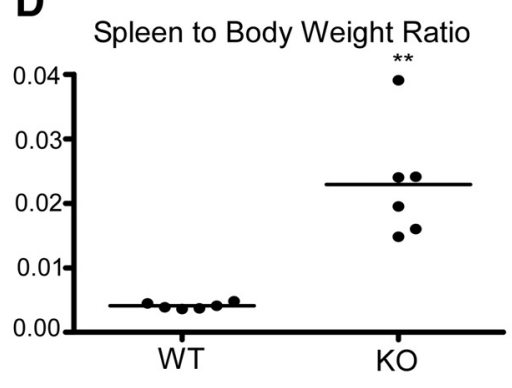

plemental Fig. 5B), consistent with an increase of IgM-producing B-1a cells.

\section{SXR is present in lymphatic tissues, and loss of function promotes lymphocyte proliferation}

SXR is highly expressed in the liver and small intestine with moderate expression in the lung, kidney, bone, and breast (1). It is controversial whether $S X R$ is expressed or functions in other tissues. Some investigators reported expression of $S X R$ and its target genes in peripheral blood mononuclear cells $(27$, 28), $\mathrm{CD}^{+}$and $\mathrm{CD} 8^{+} \mathrm{T}$ cells, $\mathrm{CD} 19^{+} \mathrm{B}$ cells, and $\mathrm{CD} 14^{+}$monocytes (29). In contrast, other investigators showed that SXR is not expressed in blood cells (30, 31). We found that $S X R$ mRNA (Fig. 3A) and protein (Fig. 3B) are detectable in the spleen, lymph nodes, and thymus. Moderate expression of SXR mRNA was found in Peyer's patches, lymph nodes, spleen, and purified B-1a cells. As expected, SXR protein was undetectable in $S X R^{-/-}$tissue (Fig. 3B).

The presence of $S X R$ mRNA and protein in lymphatic tissues, coupled with the increase in B-1 cells in $S X R^{-/-}$animals, led us to hypothesize that SXR negatively regulates lymphocyte proliferation or survival. Therefore, we tested the ability of splenocytes from 5-month-old $S X R^{-1-}$ mice to survive in culture. In the absence of exogenous stimuli, WT lymphocytes rapidly die in culture. $S X R^{-/-}$ splenocytes showed an increased number of cells (as measured by DNA content) at 48,72 , and $96 \mathrm{~h}$ as compared with the 24-h time point, whereas the number of live WT cells decreased over time (Fig. 3C). Together, these data indicate that SXR is expressed in lymphatic tissues and

\section{$S X R^{-1-}$ mice demonstrate elevated $\mathrm{Ig}$ in peripheral blood}

Patients with CLL/SLL can present with elevated serum $\operatorname{Ig}(25,26)$. Therefore, we used serum protein electrophoresis to ascertain whether serum Ig levels were altered by loss of SXR. The mean $\gamma$-globulin concentration $(0.5 \mathrm{~g} / \mathrm{dl})$ in $S X R^{-1-}$ mice was twice that of controls $(0.25 \mathrm{~g} / \mathrm{dl})$ (Supplemental Fig. 5A). The IgM concentration in the serum of $S X R^{-1-}$ animals was over 1.5 times that of controls (Sup- opposes spontaneous lymphocyte survival and proliferation.

\section{SXR regulates lymphocyte proliferation and apoptosis through NF- $\kappa$ B signaling}

We previously reported a mutually inhibitory cross talk between SXR and NF- $\kappa$ B (2). Because NF- $\kappa$ B affects cell division and proliferation through expression of $c$ $m y b$ and $c$-jun (32), we examined levels of these genes in control and $S X R^{-1-}$ spleens. As expected, quantitative 


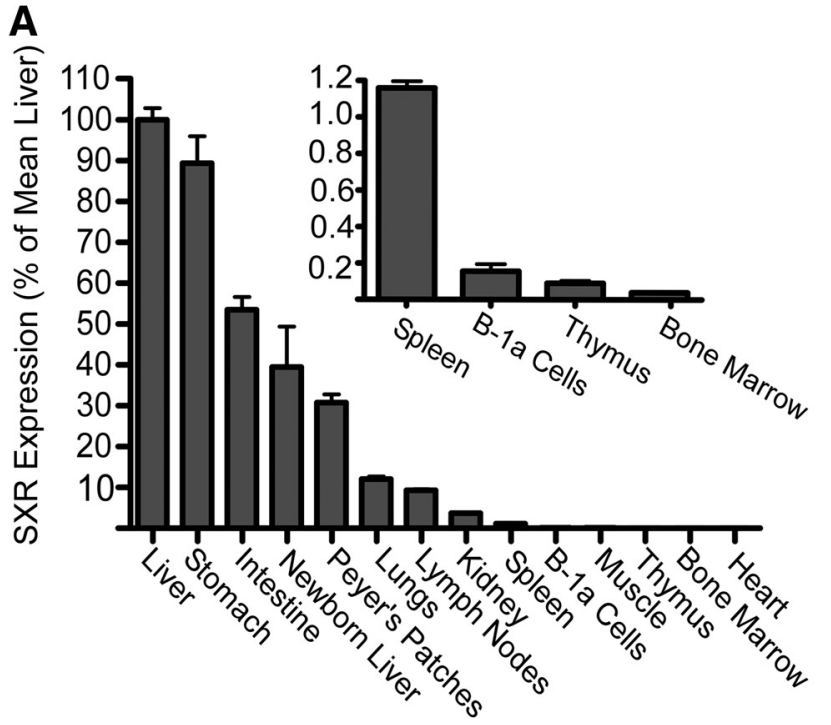

B
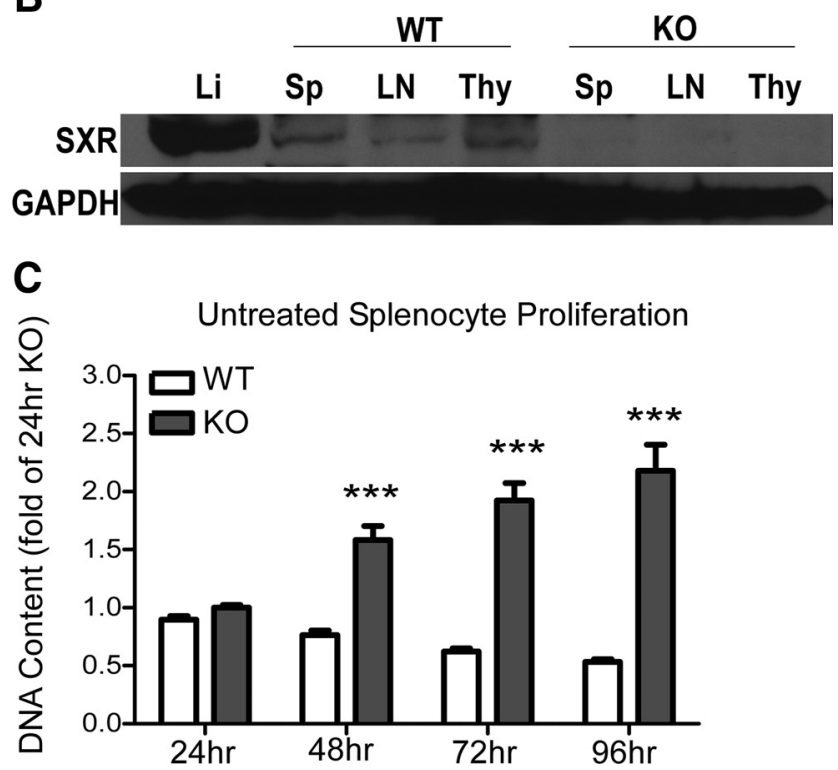

FIG. 3. SXR is present in lymphatic tissues, and loss of function promotes lymphocyte proliferation. A, SXR mRNA expression as measured by qRTPCR. All values are shown as percentage of mean liver. $B, S X R$ protein is present in liver (Li), spleen (Sp), lymph node (LN), and thymus (Thy) in WT mice, as measured by Western blot. C, SXR $R^{-1-}$ lymphocytes are proliferative in unstimulated cell culture. The 24- to 96-h time points are shown, as measured by DNA content (CyQuant). Statistical measurements are relative to $24-\mathrm{h} \mathrm{KO}$ value.

real-time PCR (qRT-PCR) analysis revealed significant increases in the expression of both genes (Fig. 4, A and B). We infer from these results that loss of SXR function leads to increased NF- $\kappa$ B function and up-regulation of proproliferation genes.

In addition to increased proliferation, we expected that changes in the levels of apoptosis could alter lymphocyte number. Accordingly, expression of the proapoptotic gene Bad was significantly decreased (Fig. 4D). The antiapoptotic $B c l-x L$ was up-regulated nearly 4 -fold compared with controls (Fig. 4C). In vivo activation of SXR in
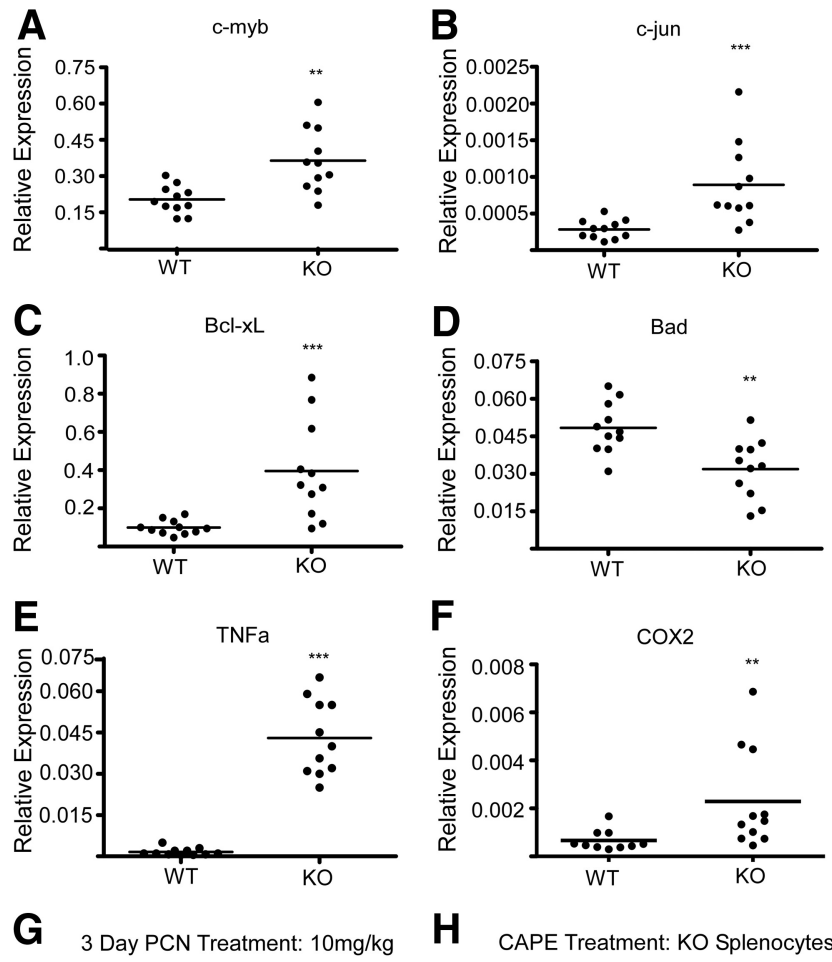

H CAPE Treatment: KO Splenocytes
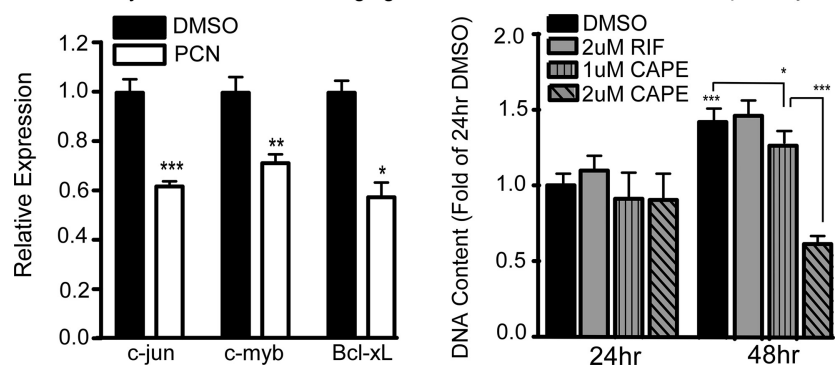

FIG. 4. SXR regulates lymphocyte proliferation and apoptosis through $N F-\kappa B$ signaling. A-D, Loss of SXR increases splenic expression of proproliferation and antiapoptotic genes and decreases splenic expression of proapoptotic genes (D) as measured by qRT-PCR; E and F, loss of $S X R$ increases splenic expression of proinflammatory SXR target genes as measured by qRT-PCR; G, qRT-PCR of WT spleen tissue after $3 \mathrm{~d}$ dimethylsulfoxide (DMSO) or PCN treatment (mean is indicated as fold of vehicle); $\mathrm{H}$, cell proliferation as measured by DNA content. The 24and 48-h treatments are shown, with dimethylsulfoxide, SXR ligand rifampicin (RIF), and 1 and $2 \mu \mathrm{M}$ CAPE treatment for each. Values are expressed as fold of 24-h dimethylsulfoxide.

WT mice by a 3-d treatment with a strong activator, pregnenolone-16-carbonitrile (PCN), led to significant downregulation of $c$-jun, $c-m y b$, and $B c l-x L$, further securing a role for SXR in cell proliferation and apoptosis (Fig. 4G). PCN-treated SXR KO animals showed no change in expression of these transcripts as compared with vehicle control, as expected (Supplemental Fig. 6).

We next sought to confirm up-regulation of NF- $\kappa \mathrm{B}$ signaling in lymphatic tissues by analyzing additional NF- $\kappa \mathrm{B}$ target genes in spleen. TNF $\alpha$ was strongly increased (Fig. 4E), and COX-2 was also significantly increased (Fig. 4F). After treatment with the NF- $\kappa$ B inhibitor caffeic acid phenethyl ester (CAPE), $B c l-x L$ was strongly down-regulated, 
and $c-m y b$ was moderately down-regulated in $S X R^{-1-}$ lymphocytes (Supplemental Fig. 7). When $S X R^{-1-}$ lymphocytes are treated in vitro with 1-2 $\mu \mathrm{M}$ CAPE, cell proliferation was reduced at both 24 and $48 \mathrm{~h}$ compared with control (Fig. $4 \mathrm{H})$, whereas the human SXR ligand rifampicin had no effect. Finally, when $S X R^{-/-}$splenocytes were stimulated in culture with lipopolysaccharide for $24 \mathrm{~h}$, quantification of $\mathrm{IgM}^{+} / \mathrm{BrdU}^{+}$cells further confirmed that $S X \mathrm{R}^{-/-} \mathrm{B}$ cells are hyperproliferative (Supplemental Fig. 8); the number of proliferating $S X R^{-1-}$ B cells tripled at $10 \mu \mathrm{g} / \mathrm{ml}$ lipopolysaccharide. Together, these results support the conclusion that loss of SXR function leads to increased proliferation and decreased apoptosis through increased NF- $\kappa$ B activity.

\section{SXR positively regulates inhibitors of B-1 cell expansion and proliferation}

After observing that $S X R^{-/-}$animals develop a B-1a cell lymphoproliferative disease and that lymphocytes from $S X R^{-/-}$animals are highly proliferative in culture, we investigated whether SXR regulates key signaling pathways in B-1 cell development. Although IL-5, IL-7, and IL-9 have been linked to modulation of the B-1 compartment (15), there was no significant difference between their expression in WT and $S X R^{-/-}$animals (Supplemental Fig. 9, A-C). Traf6 expression has been implicated in the creation of the B-1a compartment (33), but we did not observe any significant increase in Traf6 expression (Supplemental Fig. 9D). Recent work on negative regulators of B-1 cell expansion directed us toward Siglec-G, protein tyrosine phosphatase, non-receptor type 6 (PTPN6) (mouse orthologs of human Siglec-10 and $S h p 1$, respectively), $L c k$, and zeta-chain-associatedprotein kinase 70 (Zap-70). KO mice for both Siglec-G $(34,35)$ and PTPN6 $(36)$ exhibit an expansion of B-1a cells, suggesting that these proteins normally act as negative regulators of B- 1 a proliferation. $\mathrm{qRT}$-PCR analysis of splenocyte mRNA expression revealed that both $\mathrm{Si}$ glec-G (3-fold) and PTPN6 (nearly 2-fold) were downregulated in $S X R^{-/-}$animals (Fig. 5, A and B). This implicates SXR as a factor that normally promotes expression of genes that oppose B-1a cell proliferation. The Src family kinase Lck, which is normally dephosphorylated at stimulatory site Tyr-394 and down-regulated by PTPN6 $(37,38)$, is up-regulated in $S X R^{-1-}$ animals (Fig. 5C). Lck is expressed in CLL/SLL cells where it may confer self-replenishing capability $(39,40)$. Lck normally phosphorylates Zap-70 (at Tyr-319) thereby activating it (41); Zap-70 mRNA is also up-regulated in $S X R^{-1-}$ animals (Fig. 5D). Zap-70 expression has also been associated with advanced CLL and indicates a need for aggressive treatment $(42,43)$. We found that inhibitory phosphorylation of Lck on Tyr-505 was down-regulated 1.6-fold on $\mathrm{KO}$ peritoneal $\operatorname{IgM}^{+}$cells as measured by PhosFlow mean fluorescence intensity (Fig. 5E). Loss of phosphorylation at this site correlates with increased phosphorylation at Tyr-394 (44) and Lck activity. The target of Lck, Zap-70, demonstrated a 2-fold increase in stimulatory phosphorylation at Tyr-319 as quantitated by PhosFlow (Fig. 5F), confirming that Lck is active.

Next, we asked whether this B-1a cell signaling pathway was directly modulated by SXR activity in WT animals. SXR, Siglec-G, PTPN6, Lck, and Zap-70 expression were measured by qRT-PCR on tissues harvested $3 \mathrm{~d}$ after PCN treatment (Fig. 5, G and H). Siglec- $G$ was up-regulated 1.5fold in spleen and in peritoneal B-1a cells. PTPN6 was upregulated nearly 2 -fold in spleen and nearly 1.5 -fold in $\mathrm{B}-1 \mathrm{a}$ cells. $L c k$ was down-regulated 2-fold in spleen and 1.3-fold in B-1a cells. Zap-70 was down-regulated 1.3-fold in spleen and nearly 2 -fold in B-1a cells. After ligand treatment, SXR expression was also up-regulated approximately 3 -fold in both tissues (Fig. 5E). Spleens from SXR KO animals treated with PCN showed no changes in the expression of these transcripts compared with vehicle control (Supplemental Fig. 6). Finally, because loss of SXR led to up-regulation of positive regulators (Fig. 5, C and D) and down-regulation of negative regulators of this pathway (Fig. 5, A and B) and that loss of SXR led to increased activation of NF- $\kappa$ B, we hypothesized that inhibition of NF- $\kappa \mathrm{B}$ activity would reproduce the effects of activating SXR. After a 24-h treatment with CAPE, B-1a cell checkpoints PTPN6 and Siglec-G were up-regulated nearly 2 -fold in a dose-dependent manner, whereas $L c k$ was moderately down-regulated (Supplemental Fig. 4). Together, these results confirm the NF- $\kappa \mathrm{B}$-dependent role of SXR as a negative regulator of $\mathrm{B}-1$ a cell proliferation.

\section{B-1 cell tumors from $S X R^{-/-}$mice are transplantable}

We next asked whether the proliferative capacity of the B-1a cells was intrinsic to B-1a cells and whether the observed accumulations of B-1a cells represented a malignancy. Purified B-1a cells from WT or $S X R^{-1-}$ animals were transplanted into sublethally irradiated NOD/SCID recipient animals. Disease was found in spleens of mice that received B-1a cells from $S X R^{-1-}$ mice as early as $2 \mathrm{wk}$ after transplant (Fig. 6A) but not in other tissues or blood. Spleens of recipient animals increased in weight after $2 \mathrm{wk}$, with an average mass of $116.5 \mathrm{mg}$, as compared with control-treated NOD/SCID weight of $53.38 \mathrm{mg}$.

At 6 wk after transplant, animals that received $S X R^{-/-}$ B-1a cells had a mean spleen weight of $194 \mathrm{mg}$ (Fig. 6C), enlarged lymph nodes, and large numbers of $\mathrm{B}_{2} 20^{+} / \mathrm{IgM}^{+} /$ $\mathrm{CD}^{+}$cells were found in the lymph nodes (an average of $20 \%)$, spleen $(\sim 14 \%)$ unchallenged peritoneal lavage 
A

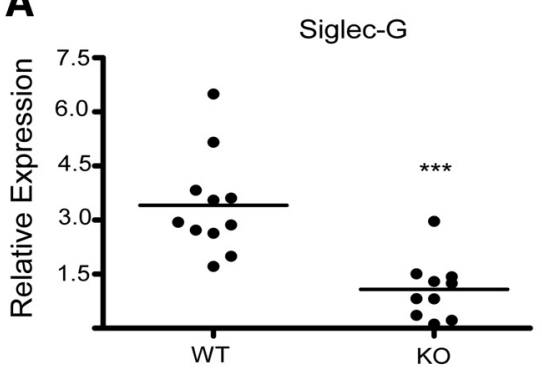

C

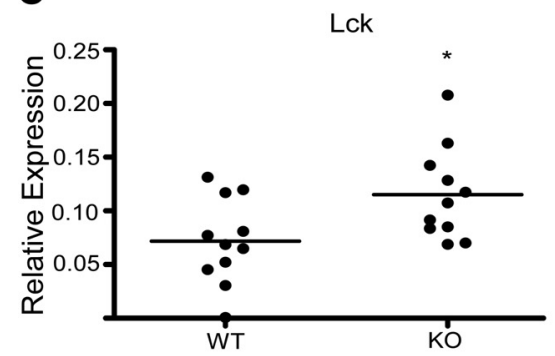

$\mathbf{E}$
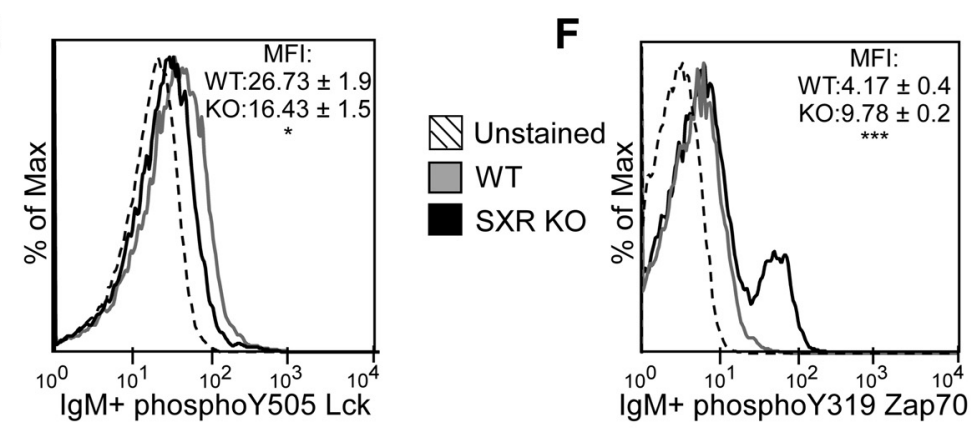

G

Spleen: 3 Day PCN: 10mg/kg

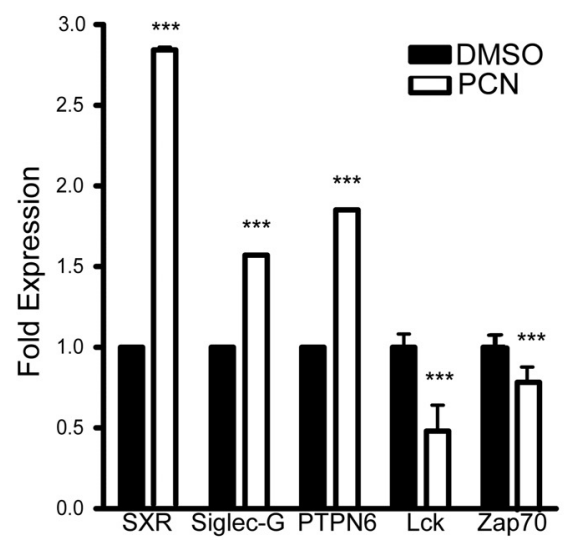

B

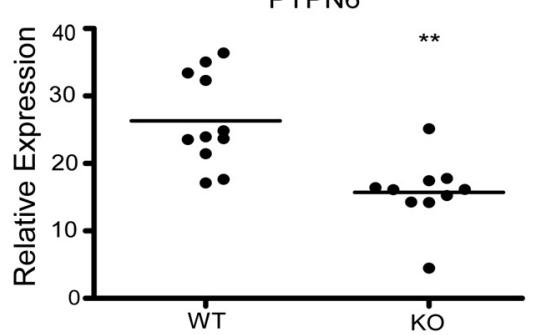

D

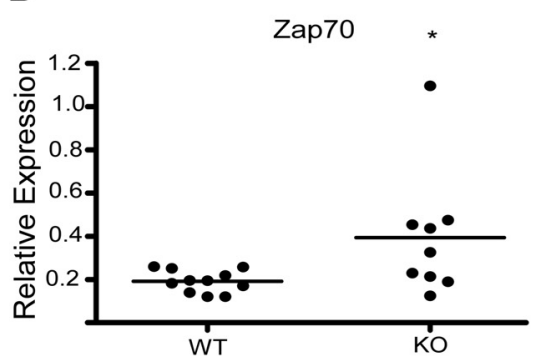

H

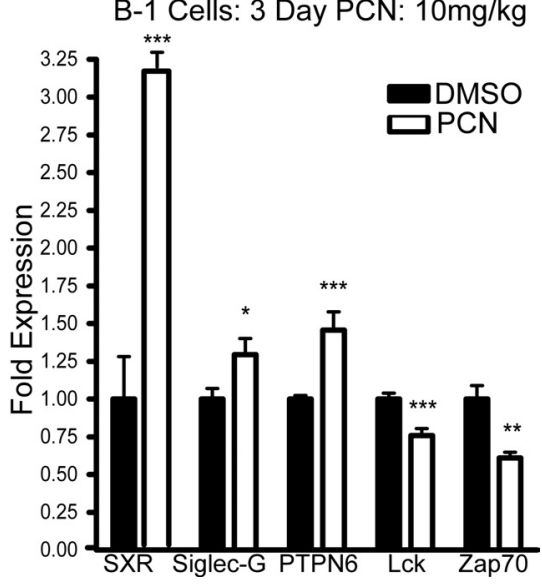

FIG. 5. SXR modulates signaling of the B-1a compartment, and ligand activation inhibits proliferation signals. A-D, SXR positively regulates negative regulators of $B-1$ cell proliferation. Expression levels of Siglec-G, PTPN6, Lck, and Zap-70 as measured by qRT-PCR relative to controls. $\mathrm{E}$ and $\mathrm{F}$, Phosflow detection of Lck and Zap-70 phosphorylation events on $\operatorname{lgM}^{+}$peritoneal $\mathrm{B}$ cells. Representative experiments for Lck Y505 and Zap-70 Y319 are shown, and the mean fluorescent intensity and SEM for all animals is indicated. $\mathrm{G}$ and $\mathrm{H}$, SXR activation inhibits B-1a cell proliferation signaling. Expression levels of Siglec-G, PTPN6, LCk, and Zap-70 are measured by qRT-PCR after $3 \mathrm{~d}$ PCN treatment via ip injection (10 $\mathrm{mg} / \mathrm{kg}$ ).

( $\sim 10 \%)$, and peripheral blood (3\%) (Fig. 6B). No B-1a cells or enlarged spleens were found in animals that were sublethally irradiated but received WT B-1a cells.

\section{Discussion}

SXR is known primarily as a regulator of the metabolism of xenobiotic, environmental, and pharmaceutical compounds that enter the body (reviewed in Ref. 1). The function of SXR as a regulator of metabolic enzyme expression in the liver and intestine is well established, yet much less is known about its functions in other tissues. We have previously shown that SXR and NF- $\kappa$ B engage in a mutually inhibitory cross talk. Therefore, considering that NF- $\kappa \mathrm{B}$ is critical for B cell development and that loss of SXR leads to increased NF- $\kappa \mathrm{B}$ signaling, we hypothesized that SXR might play an important role in lymphocyte growth and proliferation.

We found that the widespread inflammation in young $S X \mathrm{R}^{-/-}$animals progresses to a B-1a B cell lymphoma in older animals. $S X R^{-1-}$ mice develop proliferations of $\mathrm{B}-1 \mathrm{a}$ cells in the peritoneal cavity, spleen, lymph node, and peripheral blood but not in the bone marrow. $S X R^{-/-}$ mice develop enlarged spleens and lymph nodes, and their pathology resembles the human disease CLL/SLL. Gene expression analysis reveals a pivotal role of SXR in expansion of the B-1a compartment as well as regulation of proliferation and apoptosis.

We infer from these results that SXR regulates a crucial step in the development of B-1a B cells. B-1a B cells are generated almost entirely in the fetal liver $(13,16,45)$ and not in the bone marrow as are other lymphocytes, although there may be few B-1 precursors in the bone marrow that rarely give rise to B-1a cells (15). It is likely that $S X R$ expression, or the expression of one or more $S X R$ target genes, serves as a checkpoint in the development or self-renewal of B-1 B cells. SXR activity at age embryonic $\mathrm{d}$ 10-11 may be particularly important, because this is when the fetal liver begins to actively produce lymphocytes (46). B-1 cells subsequently migrate to the peritoneum where 

SXR KO B-1a Cells: 2 Weeks
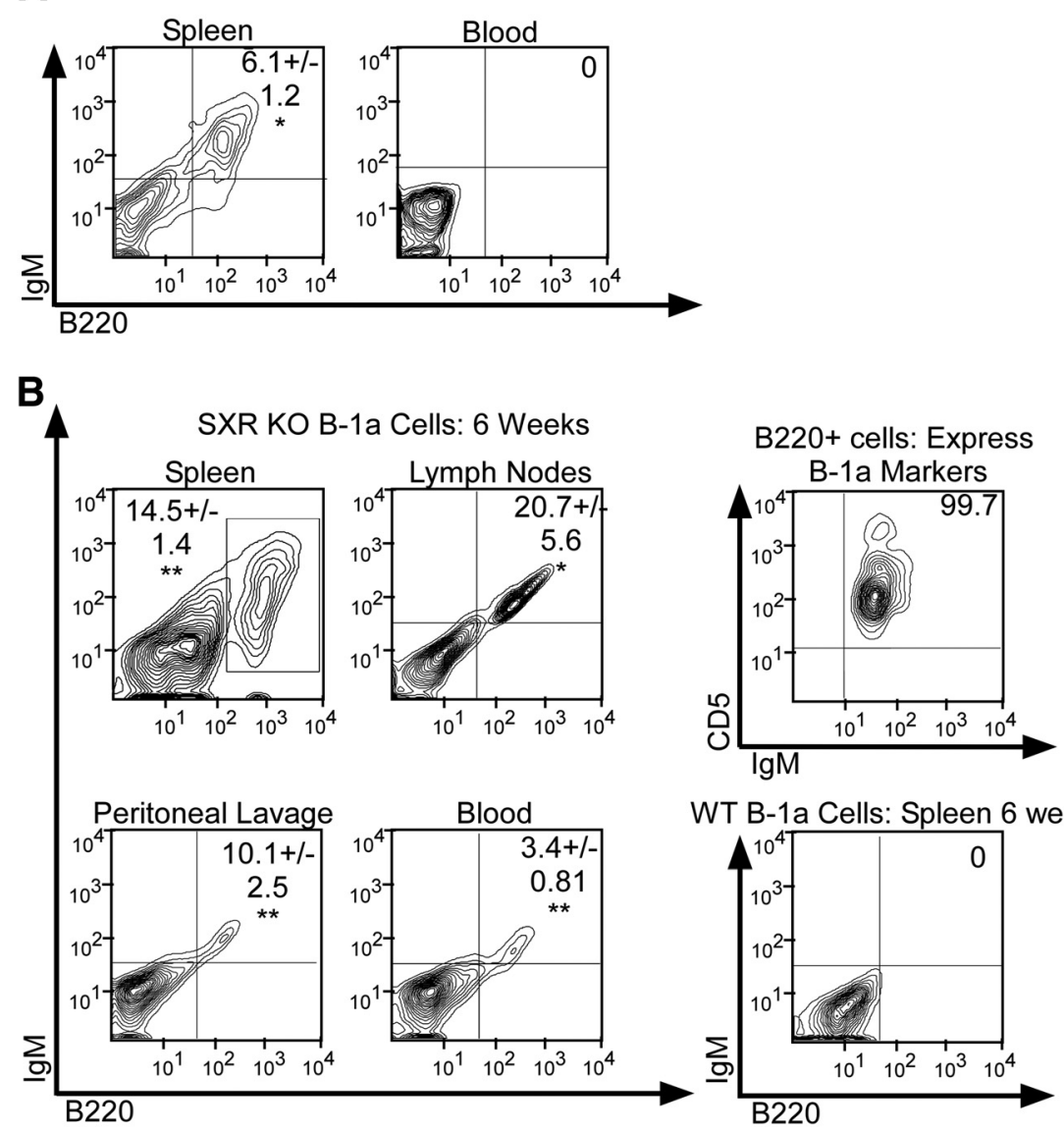

WT B-1a Cells: Spleen 6 weeks

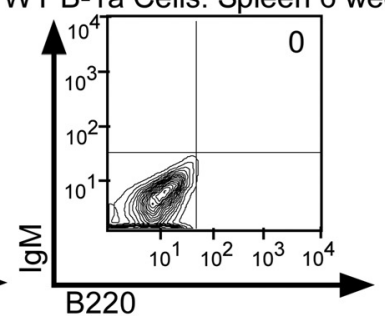

\section{C}

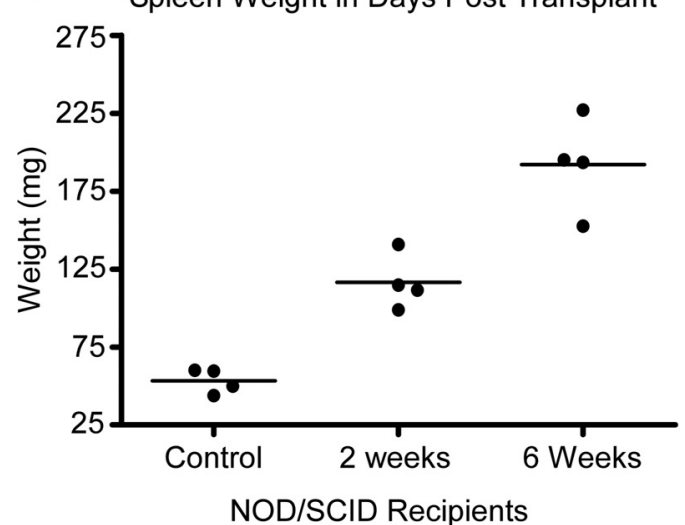

FIG. 6. B-1a lymphoproliferations from $S X R^{-1-}$ animals are transplantable. A, B-1a cells are found in spleen of NOD/SCID recipient animals 2 wk after transplant. Peripheral blood shows no B-1a cells. B, B-1a cells are found in spleen, lymph nodes, unchallenged peritoneal lavage, and blood 6 wk after transplant as measured by flow cytometry. C, Spleen weight (milligrams) of NOD/SCID recipient animals 2 and 6 wk after transplant.

they continue to self-replenish; SXR may continue to function as a checkpoint for B-1 cell growth and proliferation throughout life. It is also notable that the liver and gut are locations of high SXR expression and activity in WT animals, suggesting that regulation of lymphocyte proliferation in these tissues may be an important but overlooked function of SXR.
There is a growing body of evidence showing that nuclear receptors play important roles in regulating proliferation of lymphoid cells. Bensinger et al. (47) recently showed that loss of the nuclear receptor liver $\mathrm{X}$ receptor resulted in enhanced proliferation of $\mathrm{T}$ cells, linking sterol metabolism to the acquired immune response. Coste et al. (48) showed B cell lymphoma in aged steroid receptor coactivator-3 null mice. Mice lacking the retinoid-related orphan receptor ROR $\gamma$ exhibited lymphocyte accumulations in the spleen (49) and T cell lymphoma (50), and animals lacking the nuclear receptors $\mathrm{Nr} 4 \mathrm{a} 3$ and Nr4a1 develop acute myeloid leukemia (51). These data show that nuclear hormone receptors play key roles in regulating lymphocyte proliferation.

The association between SXR loss of function and lymphoma provides an important and potentially causal link between xenobiotic chemicals and tumor formation. Our results suggest that compounds that inactivate SXR may lead to chronic inflammation and to lymphomas over time. Xenobiotic chemicals and pollutants have been associated with increased risk of nonHodgkin's lymphoma, particularly polychlorinated biphenyls (PCB) $(52,53)$. We have previously shown that highly chlorinated PCB are antagonists of human SXR (54). Notable among the PCB that antagonize SXR and those that have been associated with increased risk of non-Hodgkin's lymphoma is PCB153. Therefore, our results suggest a potential mechanistic link between xenobiotic chemicals that antagonize SXR and the development of lymphatic cancers.

Although data linking SXR to cancers are scant, analysis of microarray data from a variety of cancers deposited in Oncomine suggests a potential association between reduced SXR expression and lymphatic malignancies. It is not possible at this time to determine whether SXR down-regulation is causal in these cancers or instead represents the result of NF- $\kappa \mathrm{B}$ inhibiting SXR expression. Our ongoing studies 
aim to examine SXR polymorphisms, expression, and activity in human lymphomas. SXR expression in untreated tumors will be of particular interest, because chemotherapeutic agents may lead to an up-regulation of SXR expression, thereby masking down-regulation of SXR in the initial tumor. It will also be important to determine whether SXR agonists have clinical utility in treating lymphatic tumors, particularly those driven by aberrantly high NF- $\kappa$ B activity.

Overall, our findings are consistent with a model in which down-regulation, repression, or loss of SXR function may play a key role in the development of B cell lymphoma. Thus, SXR unexpectedly functions as a tumor suppressor in B-1 cells. These data also suggest a role for SXR as an important modulator of immune function and environmental sensing beyond its role as a xenobiotic receptor. It is possible, albeit unproven, that SXR works cooperatively with the B-1 cell compartment to detect foreign threats. This work establishes a pivotal role for SXR in cell fate decisions at the crossroads of the innate and adaptive immune response, and secures a role for SXR in the regulation of the B-1 lymphocyte compartment and as a potential therapeutic target for diseases such as B cell malignancies.

\section{Materials and Methods}

\section{Lymphocyte analysis and flow cytometry}

Tissues were manually dissociated and strained to remove debris, and lysis buffer $\left[0.15 \mathrm{M} \mathrm{NH}_{4} \mathrm{Cl}, 10 \mathrm{~mm} \mathrm{KHCO}_{3}, 0.1 \mathrm{~mm}\right.$ EDTA ( $\mathrm{pH}$ 7.3)] was used to remove red blood cells. Blood samples were mixed with $5 \mathrm{~mm}$ EDTA, and red blood cells were lysed. Cells were washed and resuspended in cold flow cytometry buffer ( $1 \%$ fetal bovine serum, $0.1 \%$ sodium azide in PBS). Antibodies were purchased from BD Bioscience (San Jose, CA) (CD5 allophycocyanin (APC), B220 fluorescein isothiocyanate (FITC), IgD APC, IgM phycoerythrin (PE), and IgM APC), BD PhosFlow (Alexa Fluor 488 Lck pY505 and PE Zap-70 Y319), eBioscience (San Diego, CA) (CD3 PE, CD3 phycoerythrin-cyanin 5.5 (PE-Cy 5.5), CD8 APC, B220 PE-Cy5.5, IgD FITC, CD4 PE-Cy5.5, CD11b FITC, CD11c PE, CD21 FITC, CD25 PE, CD38 FITC, and Gr-1 PE), Biolegend (San Diego, CA) (Ig light chain $\lambda$ ), and Invitrogen Zymed (Carlsbad, CA) (Ig light chain $\kappa$ $\mathrm{PE}$ ), and staining was performed according to the manufacturer's protocol. Biotinylated Ig light chain $\lambda$ was detected with streptavidin-FITC (eBioscience, San Diego, CA). Cells were analyzed on FACSCalibur (Becton Dickinson, Mountain View, CA) and data were analyzed using FlowJo (Treestar, Ashland, OR). Each plot is representative of three or more animals.

\section{Proliferation studies}

Single-cell suspensions were prepared by manual dissociation, straining, and red blood cell lysis. Cells were grown at 5\% $\mathrm{CO}_{2}$ at $37 \mathrm{C}$ in RPMI 1640 supplemented with $50 \mu \mathrm{M} 2$-mercaptoethanol, $10 \%$ fetal calf serum, $100 \mathrm{U} / \mathrm{ml}$ penicillin, 100 $\mu \mathrm{g} / \mathrm{ml}$ streptomycin, $2 \mathrm{~mm}$ L-glutamine, and $10 \mathrm{~mm}$ HEPES in round-bottom 96-well plates. CyQuant proliferation assay (Invitrogen) was performed as described (55).

\section{RNA isolation, cDNA preparation, and qRT-PCR}

RNA was isolated using TRIzol reagent (Invitrogen) according to the manufacturer's protocol. cDNA was synthesized using SuperScript III (Invitrogen). qRT-PCR was performed using specific primers (Supplemental Table 1) and the SYBR Green QPCR kit (Applied Biosystems, Foster City, CA) in a DNA Engine Opticon fluorescence detection system (Bio-Rad, Hercules, CA). Data were analyzed using the cycle threshold method (normalized to GAPDH). Peritoneal B-1a cells were purified using magnetic beads (Miltenyi Biotec, Auburn, CA) to deplete CD90.2 and enrich for CD5.

\section{Western blotting}

Tissues were homogenized in ice-cold RIPA buffer [137 mM $\mathrm{NaCl}, 20 \mathrm{~mm}$ Tris- $\mathrm{HCl}$ (pH 7.5), $1 \%$ Triton X-100, $0.5 \%$ Nonidet P-40, 10\% glycerol, 2 mm EDTA ( $\mathrm{pH}$ 8.0)] plus protease inhibitors (RPI Corp., Mt. Prospect, Illinois). Proteins were separated on $10 \%$ SDS-PAGE gels and were transferred to Immobilon membrane (Millipore, Billerica, MA) using the semi-dry method (Bio-Rad, Hercules, CA). Western blot analysis was performed as previously described (55), and bands were detected using the ECL Plus Western blotting detection system (Amersham Bioscience, Piscataway, NJ).

\section{Cloning and sequencing}

$\mathrm{V}_{\mathrm{H}} \mathrm{DJ}_{\mathrm{H}^{-}}$-Cmu transcripts were amplified from cDNA with a universal Vh FR1 forward primer (5'-SARGTNMAGCTGSAGSAGTC-3') and a Cmu reverse primer (5'-CTTATCAGACAGGGGGCTCT-3') using a Biolase DNA polymerase (Bioline, Tauton, MA). Cloning was performed using TOPO-TA cloning kit for sequencing (Invitrogen), and DNA was purified using a miniprep kit (Zyppy, Zymo Research, Irvine, CA). GeneWiz performed sequencing using an M13R primer, and sequences were aligned using multiple alignment program for amino acid or nucleotide sequences (MAFFT version 6).

\section{Lymphocyte transplantation studies}

B-1a cells were harvested from $S X R^{-1-}$ spleens or unchallenged peritoneal lavage of control mice. Cells were depleted for CD90.2 and enriched for CD5 using magnetic beads (Miltenyi Biotec). Both WT and SXR KO cells were determined to be approximately $92 \%$ pure as determined by flow cytometry (Supplemental Fig. 10), and $2.5 \times 10^{5} \mathrm{SXR}^{-1-}$ or WT cells were injected into the retroorbital venous sinus of 8 -wk-old NOD/ SCID animals that had received $250 \mathrm{cGy}$ total body irradiation. Recipient mice were divided into two arms of the experiment $(2$ and $6 \mathrm{wk})$. Mice were euthanized when they showed symptoms of chronic disease; $25 \%$ of KO-recipient mice were euthanized at $41 \mathrm{~d}$, and $75 \%$ were euthanized at $45 \mathrm{~d}$. Mice that received 250 cGy total body irradiation but received control cells (WT B-1a cells) were monitored for $12 \mathrm{wk}$ after transplant, and none developed disease.

\section{Animals and histological evaluation}

Animals were identically raised and housed at the University of California, Irvine, and were maintained on a standard diet. 
For histology, tissues were fixed in $4 \%$ buffered formalin, embedded in paraffin, and sectioned and stained with hematoxylin and eosin. Serum protein electrophoresis and rate nephelometry (IgM) were performed by University of California, Irvine, Pathology Services. Animal care and use was in accordance with applicable standards and approved by the Institutional Animal Care and Use Committees at the University of California, Irvine. $S X R^{-1-}$ mice were descendents of a gift from the Salk Institute; all other animals were purchased from Taconic Farms (Germantown, NY).

\section{Statistics}

Differences between groups were analyzed using Student's $t$ test (parametric) or Mann-Whitney $U$ test (nonparametric). A $P$ value $<0.05$ was considered to be significant, and is indicated by a single asterisk, whereas $P<0.01$ is indicated by two asterisks, and $P<0.001$ is indicated by three asterisks. Graphs are presented as the mean \pm SEM. Analyses were performed with Prism 4 program (GraphPad Software, San Diego, CA).

\section{Acknowledgments}

We thank Suman Verma, Amanda K. Laust, and Egest J. Pone for technical assistance. We also thank Hong Zan and Paolo Casali for $\mathrm{V}_{\mathrm{H}} \mathrm{DJ}_{\mathrm{H}^{-}}$Cmu primer sequences.

Address all correspondence and requests for reprints to: B. Blumberg, Developmental and Cell Biology, 2011 Biological Sciences 3, University of California, Irvine, California 926972300. E-mail: blumberg@uci.edu.

We acknowledge support from National Institutes of Health Grants T32 CA9054 (to S.C.C. and M.R.J.) and ES015849 (to B.B.) and a Research Scholar Grant from the American Cancer Society (to D.A.F.).

S.C.C. designed and performed experiments, analyzed data, and wrote the paper. E.L.N. jointly conceived the study with S.C.C. and B.B. and performed pathology analysis. G.M.T. performed experiments. M.R.J. performed experiments and advised on chronic disease studies. D.A.F. designed experiments, provided reagents and animals, and provided experimental advice. B.B. designed experiments, supervised data collection and analysis, and wrote the paper.

Disclosure Summary: S.C.C., E.L.N., G.M.T., M.R.J., and D.A.F. have nothing to declare. B.B. is a named inventor on U.S. patents US 6,756,491, US 6,809,178, US 6,984,773, and US 7,214,482 related to SXR.

\section{References}

1. Zhou C, Verma S, Blumberg B 2009 The steroid and xenobiotic receptor (SXR), beyond xenobiotic metabolism. Nucl Recept Signal 7:e001

2. Zhou C, Tabb MM, Nelson EL, Grün F, Verma S, Sadatrafiei A, Lin M, Mallick S, Forman BM, Thummel KE, Blumberg B $2006 \mathrm{Mu}-$ tual repression between steroid and xenobiotic receptor and NF- $\kappa \mathrm{B}$ signaling pathways links xenobiotic metabolism and inflammation. J Clin Invest 116:2280-2289

3. Gu X, Ke S, Liu D, Sheng T, Thomas PE, Rabson AB, Gallo MA, Xie W, Tian Y 2006 Role of NF- $\kappa$ B in regulation of PXR-mediated gene expression: a mechanism for the suppression of cytochrome P-450 3A4 by proinflammatory agents. J Biol Chem 281:1788217889

4. Sarkar FH, Li Y, Wang Z, Kong D 2008 NF- $\kappa$ B signaling pathway and its therapeutic implications in human diseases. Int Rev Immunol 27:293-319

5. Sagaert X, De Wolf-Peeters C, Noels H, Baens M 2007 The pathogenesis of MALT lymphomas: where do we stand? Leukemia 21: 389-396

6. Mantovani A, Allavena P, Sica A, Balkwill F 2008 Cancer-related inflammation. Nature 454:436-444

7. Karin M 2009 NF- $\kappa$ B as a critical link between inflammation and cancer. Cold Spring Harbor Perspect Biol 1:a000141

8. Pikarsky E, Porat RM, Stein I, Abramovitch R, Amit S, Kasem S, Gutkovich-Pyest E, Urieli-Shoval S, Galun E, Ben-Neriah Y 2004 $\mathrm{NF}-\kappa \mathrm{B}$ functions as a tumour promoter in inflammation-associated cancer. Nature 431:461-466

9. Greten FR, Eckmann L, Greten TF, Park JM, Li ZW, Egan LJ, Kagnoff MF, Karin M 2004 IKK $\beta$ links inflammation and tumorigenesis in a mouse model of colitis-associated cancer. Cell 118:285296

10. Ansar Ahmed S, Penhale WJ, Talal N 1985 Sex hormones, immune responses, and autoimmune diseases. Mechanisms of sex hormone action. Am J Pathol 121:531-551

11. Grossman CJ 1984 Regulation of the immune system by sex steroids. Endocr Rev 5:435-455

12. Homo-Delarche F, Fitzpatrick F, Christeff N, Nunez EA, Bach JF, Dardenne M 1991 Sex steroids, glucocorticoids, stress and autoimmunity. J Steroid Biochem Mol Biol 40:619-637

13. Hardy RR, Hayakawa K 1994 CD5 B cells, a fetal B cell lineage. Adv Immunol 55:297-339

14. Dorshkind K, Montecino-Rodriguez E 2007 Fetal B-cell lymphopoiesis and the emergence of B-1-cell potential. Nat Rev Immunol 7:213-219

15. Hardy RR 2006 B-1 B cells: development, selection, natural autoantibody and leukemia. Curr Opin Immunol 18:547-555

16. Hayakawa K, Hardy RR 2000 Development and function of B-1 cells. Curr Opin Immunol 12:346-353

17. Lopez-Matas M, Rodriguez-Justo M, Morilla R, Catovsky D, Matutes E 2000 Quantitative expression of CD23 and its ligand CD21 in chronic lymphocytic leukemia. Haematologica 85:11401145

18. Moreno C, Montserrat E 2008 New prognostic markers in chronic lymphocytic leukemia. Blood Rev 22:211-219

19. McGuire KL, Vitetta ES $1981 \kappa / \lambda$ Shifts do not occur during maturation of murine B cells. J Immunol 127:1670-1673

20. Woloschak GE, Krco CJ 1987 Regulation of $\kappa / \lambda$ immunoglobulin light chain expression in normal murine lymphocytes. Mol Immunol 24:751-757

21. Kaneita Y, Yasukawa K, Kura Y, Yamazaki T, Sawada U 2000 [Phenotypic classification of malignant lymphoma]. Nippon Rinsho 58:586-590 (Japanese)

22. Davidson B, Risberg B, Berner A, Smeland EB, Torlakovic E 1999 Evaluation of lymphoid cell populations in cytology specimens using flow cytometry and polymerase chain reaction. Diagn Mol Pathol 8:183-188

23. Rundles RW, Moore JO 1978 Chronic lymphocytic leukemia. Cancer 42:941-945

24. Stall AM, Fariñas MC, Tarlinton DM, Lalor PA, Herzenberg LA, Strober S, Herzenberg LA 1988 Ly-1 B-cell clones similar to human chronic lymphocytic leukemias routinely develop in older normal mice and young autoimmune (New Zealand Black-related) animals. Proc Natl Acad Sci USA 85:7312-7316

25. Yin CC, Lin P, Carney DA, Handy BC, Rassidakis GZ, Admirand JH, Keating MJ, Medeiros LJ 2005 Chronic lymphocytic leukemia/ small lymphocytic lymphoma associated with IgM paraprotein. Am J Clin Pathol 123:594-602

26. Hansen DA, Robbins BA, Bylund DJ, Piro LD, Saven A, Ellison DJ 
1994 Identification of monoclonal immunoglobulins and quantitative immunoglobulin abnormalities in hairy cell leukemia and chronic lymphocytic leukemia. Am J Clin Pathol 102:580-585

27. Albermann N, Schmitz-Winnenthal FH, Z'graggen K, Volk C, Hoffmann MM, Haefeli WE, Weiss J 2005 Expression of the drug transporters MDR1/ABCB1, MRP1/ABCC1, MRP2/ABCC2, BCRP/ABCG2, and PXR in peripheral blood mononuclear cells and their relationship with the expression in intestine and liver. Biochem Pharmacol 70:949-958

28. Siest G, Jeannesson E, Marteau JB, Samara A, Marie B, Pfister M, Visvikis-Siest S 2008 Transcription factor and drug-metabolizing enzyme gene expression in lymphocytes from healthy human subjects. Drug Metab Dispos 36:182-189

29. Schote AB, Turner JD, Schiltz J, Muller CP 2007 Nuclear receptors in human immune cells: expression and correlations. Mol Immunol 44:1436-1445

30. Bookout AL, Jeong Y, Downes M, Yu RT, Evans RM, Mangelsdorf DJ 2006 Anatomical profiling of nuclear receptor expression reveals a hierarchical transcriptional network. Cell 126:789-799

31. Barish GD, Downes M, Alaynick WA, Yu RT, Ocampo CB, Bookout AL, Mangelsdorf DJ, Evans RM 2005 A nuclear receptor atlas: macrophage activation. Mol Endocrinol 19:2466-2477

32. Zhang MY, Sun SC, Bell L, Miller BA 1998 NF- $\kappa$ B transcription factors are involved in normal erythropoiesis. Blood 91:41364144

33. Kobayashi T, Kim TS, Jacob A, Walsh MC, Kadono Y, FuentesPananá E, Yoshioka T, Yoshimura A, Yamamoto M, Kaisho T, Akira S, Monroe JG, Choi Y 2009 TRAF6 is required for generation of the B-1a B cell compartment as well as T cell-dependent and -independent humoral immune responses. PLoS ONE 4:e4736

34. Hoffmann A, Kerr S, Jellusova J, Zhang J, Weisel F, Wellmann U, Winkler TH, Kneitz B, Crocker PR, Nitschke L 2007 Siglec-G is a B1 cell-inhibitory receptor that controls expansion and calcium signaling of the B1 cell population. Nat Immunol 8:695-704

35. Ding C, Liu Y, Wang Y, Park BK, Wang CY, Zheng P, Liu Y 2007 Siglecg limits the size of $\mathrm{B} 1 \mathrm{a} \mathrm{B}$ cell lineage by down-regulating $\mathrm{NF} \kappa \mathrm{B}$ activation. PLoS ONE 2:e997

36. Pao LI, Lam KP, Henderson JM, Kutok JL, Alimzhanov M, Nitschke L, Thomas ML, Neel BG, Rajewsky K 2007 B cell-specific deletion of protein-tyrosine phosphatase Shp1 promotes B-1a cell development and causes systemic autoimmunity. Immunity 27 : $35-48$

37. Chiang GG, Sefton BM 2001 Specific dephosphorylation of the Lck tyrosine protein kinase at Tyr-394 by the SHP-1 protein-tyrosine phosphatase. J Biol Chem 276:23173-23178

38. Cuevas B, Lu Y, Watt S, Kumar R, Zhang J, Siminovitch KA, Mills GB 1999 SHP-1 regulates Lck-induced phosphatidylinositol 3kinase phosphorylation and activity. J Biol Chem 274:27583-27589

39. Majolini MB, D’Elios MM, Galieni P, Boncristiano M, Lauria F, Del Prete G, Telford JL, Baldari CT 1998 Expression of the T-cellspecific tyrosine kinase Lck in normal B-1 cells and in chronic lymphocytic leukemia B cells. Blood 91:3390-3396

40. Abts H, Jücker M, Diehl V, Tesch H 1991 Human chronic lymphocytic leukemia cells regularly express mRNAs of the protooncogenes lck and c-fgr. Leuk Res 15:987-997
41. Kolanus W, Romeo C, Seed B 1993 T cell activation by clustered tyrosine kinases. Cell 74:171-183

42. Rassenti LZ, Huynh L, Toy TL, Chen L, Keating MJ, Gribben JG, Neuberg DS, Flinn IW, Rai KR, Byrd JC, Kay NE, Greaves A, Weiss A, Kipps TJ 2004 ZAP-70 compared with immunoglobulin heavychain gene mutation status as a predictor of disease progression in chronic lymphocytic leukemia. N Engl J Med 351:893-901

43. Schroers R, Griesinger F, Trümper L, Haase D, Kulle B, KleinHitpass L, Sellmann L, Dührsen U, Dürig J 2005 Combined analysis of ZAP-70 and CD38 expression as a predictor of disease progression in B-cell chronic lymphocytic leukemia. Leukemia 19:750-758

44. Marth JD, Cooper JA, King CS, Ziegler SF, Tinker DA, Overell RW, Krebs EG, Perlmutter RM 1988 Neoplastic transformation induced by an activated lymphocyte-specific protein tyrosine kinase (pp56lck). Mol Cell Biol 8:540-550

45. Kantor AB, Herzenberg LA 1993 Origin of murine B cell lineages. Annu Rev Immunol 11:501-538

46. Houssaint E 1981 Differentiation of the mouse hepatic primordium. II. Extrinsic origin of the haemopoietic cell line. Cell Differ 10:243-252

47. Bensinger SJ, Bradley MN, Joseph SB, Zelcer N, Janssen EM, Hausner MA, Shih R, Parks JS, Edwards PA, Jamieson BD, Tontonoz P 2008 LXR signaling couples sterol metabolism to proliferation in the acquired immune response. Cell 134:97-111

48. Coste A, Antal MC, Chan S, Kastner P, Mark M, O'Malley BW, Auwerx J 2006 Absence of the steroid receptor coactivator-3 induces B-cell lymphoma. EMBO J 25:2453-2464

49. Zhang N, Guo J, He YW 2003 Lymphocyte accumulation in the spleen of retinoic acid receptor-related orphan receptor gammadeficient mice. J Immunol 171:1667-1675

50. Ueda E, Kurebayashi S, Sakaue M, Backlund M, Koller B, Jetten AM 2002 High incidence of T-cell lymphomas in mice deficient in the retinoid-related orphan receptor $\operatorname{ROR} \gamma$. Cancer Res 62:901909

51. Mullican SE, Zhang S, Konopleva M, Ruvolo V, Andreeff M, Milbrandt J, Conneely OM 2007 Abrogation of nuclear receptors $\mathrm{Nr} 4 \mathrm{a} 3$ and $\mathrm{Nr} 4 \mathrm{a} 1$ leads to development of acute myeloid leukemia. Nat Med 13:730-735

52. De Roos AJ, Hartge P, Lubin JH, Colt JS, Davis S, Cerhan JR, Severson RK, Cozen W, Patterson Jr DG, Needham LL, Rothman N 2005 Persistent organochlorine chemicals in plasma and risk of non-Hodgkin's lymphoma. Cancer research 65:11214-11226

53. Engel LS, Laden F, Andersen A, Strickland PT, Blair A, Needham LL, Barr DB, Wolff MS, Helzlsouer K, Hunter DJ, Lan Q, Cantor KP, Comstock GW, Brock JW, Bush D, Hoover RN, Rothman N 2007 Polychlorinated biphenyl levels in peripheral blood and nonHodgkin's lymphoma: a report from three cohorts. Cancer Res 67:5545-5552

54. Tabb MM, Kholodovych V, Grün F, Zhou C, Welsh WJ, Blumberg B 2004 Highly chlorinated PCB inhibit the human xenobiotic response mediated by the steroid and xenobiotic receptor (SXR). Environ Health Perspect 112:163-169

55. Verma S, Tabb MM, Blumberg B 2009 Activation of the steroid and xenobiotic receptor, SXR, induces apoptosis in breast cancer cells. BMC cancer 9:3 